\title{
Origin and ecological heterogeneity of Baropal wetland: A Review
}

\author{
Malhotra, G.S. ${ }^{1}$ 网, Madan, $\mathbf{J}^{2}$
}

Received: 10.08 .2020

Revised: 13.10.2020

Accepted: 03.11.2020

\begin{abstract}
Baropal wetland is situated near to the Baropal village, Pilibanga tehsil of Hanumangarh District in Rajasthan state (290 22' 10" North, $74^{0} \mathbf{0 5}, 48$ " East) and comes under the Ghaggar river floodplain. Baropal wetland is a recently and naturally originated water body, presumably recharged by the seepage water of Ghaggar river and Indira Gandhi Canal Project (IGNP). It is a real example of rapid succession and species aggregation in the barren land and has been established as a rich biodiversity amphitheatre within the semi-desert region. The vegetation cover of Baropal wetland stretch has changed into Xerophytic to Mesophytic and Hydrophytic. As, it has established enormous plant and animal communities in a short period, in the present picture, the plant communities of Baropal wetland are much productive to support enough food and habitat to a variety of organisms. Unfortunately, Baropal wetland has not received any ecological attention despite being a water body and always ignored due to the inadequacy in the number of the wellestablished local researchers. Its beauty has always been superimposed by the fascinating archaeological sites which are present in the same locality (Ghaggar floodplain) and by the Ghaggar and Saraswati debate.
\end{abstract}

Key Words: Baropal wetland, Ecological heterogeneity, Ghaggar river, Indira Gandhi Canal Project (IGNP).

\section{Introduction}

Wetlands are very significant entities for the ecological services and ecosystem health. Since wetlands are very productive areas, therefore, they serve large and diverse communities of plants and animals (Keddy, 2010). The origin of a wetland is the outcome of unusual geological activities and natural forces. In the inland region, usually, wetlands come to existence through an alteration in the drainage pattern of a river system by developmental activities or sediment deposition/erosion in river floodplains by the natural activities (Tiner, 2016). The origin of Baropal wetland is the live example of alteration in the drainage pattern of a river system. Three decades earlier, it came to the existence in the Ghaggar river floodplain through considerable modification in land use pattern (Moharana, 2012). After the origin, this riparian wetland has changed the topography of the local area and proved itself an ecologically significant site. On the other side, the adjoining area of Baropal wetland is also engrossing due to and presence of the Indus Valley

\section{Author's Address}

${ }^{1}$ Mody University of Science and Technology, Laxmangarh, Rajasthan, India

${ }^{2}$ S.A.V. Jain Girls P.G. College, Sri Ganganagar, Rajasthan, India

E-mail.: gurmeet.malhotra@gmail.com
Civilisation patches in the floodplain area of Ghaggar river (Thapar, 1975; Mamatamayee, 1991). The paper is attempting to cover the geological and ecological aspects of the Baropal wetland and its adjoining area. The connection among Baropal wetland, Ghaggar river and Indira Gandhi Canal Project (IGNP) is much obvious to demystify the origin of Baropal Wetland.

\section{Baropal Wetland}

Baropal wetland is situated near to the Baropal village, Pilibanga tehsil of Hanumangarh District in Rajasthan state $\left(29^{0} 22^{\prime} 10^{\prime \prime}\right.$ North, $74^{0} 05^{\prime} 48^{\prime \prime}$ East) and comes under the Ghaggar river floodplain. Baropal wetland is a recently and naturally originated water body, presumably recharged by the seepage water of Ghaggar river and Indira Gandhi Canal Project (IGNP). Baropal wetland is a shallow and brackish water body. Its average depth falls under 1.5 meter and covers 12 square $\mathrm{km}$ total land area. Some small land patches are also visible under the wetland that are observed to work as resting sites for birds and insects. Baropal wetland has relatively open water, welldefined edges, contains water for the entire season, and is relatively free from human interference. The water chemistry analysis confirms the high salinity and high concentration of alkali metals in the 
Malhotra and Madan
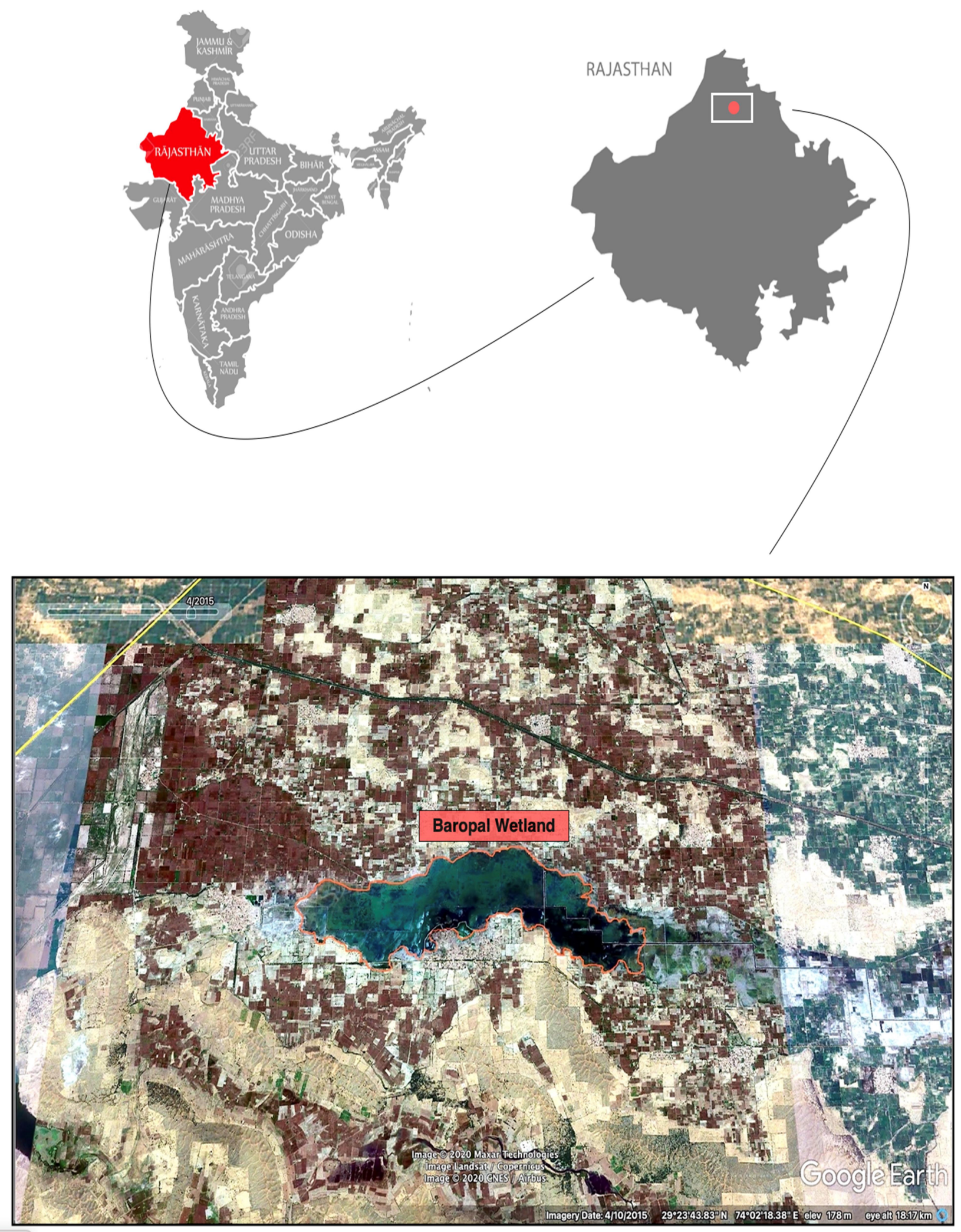

Figure 1. Location and Satellite view of the Baropal Wetland (Source: Google Earth, 2015).

166

Environment Conservation Journal 
wetland water (Garg and Soni, 2016). The precipitated salt can also be seen on the adjacent vegetational line. It is an ecologically significant site due to a riparian zone and rich biodiversity.

\section{Climate}

The climate of the adjoining area of the Baropal wetland is semi-arid. Winter remains from November to March with cold and dry conditions. Summer remains from April to July with heated and dry conditions, further which cause frequent south-west dust storms. The average annual temperature of the region falls between $24^{0}$ to $26^{\circ} \mathrm{C}$; the rainfall falls between $250-300 \mathrm{~mm}$, and humidity tends to remain between $60-65 \%$. Precisely, precipitation is extremely variable in the region and sometimes, it suffers from severe drought (Dwivedi and Sreenivas, 2002). Typically, maximum rainfall is received during the monsoon season. The rainy season begins in July and ends by the mid of September. The weather remains mild and pleasant during September to October.

\section{Geomorphology}

The terrain of the adjoining area of Baropal wetland is composed of alluvial sandy-loam soil. The study reveals that it was formed by Quaternary alluvial overlain, and there is no presence of rocks or gravel material at the surface (Sinha-Roy et al., 1998; Ramakrishnan and Vaidyanadhan, 2010). More correctly, lithologically, it is an alluvial plain of the Ghagghar river, which has been buried by windblown material at the succeeding stage. Accordingly, it represents both an aeolian land system and the fluvial system of Ghaggar riverbed. The sub-surface of the region contains gypsum and clay that work as a hydrological barrier therefore, subsurface drainage is extremely poor. Topographically, the region denotes sand-dunes and interdunal depressions with ephemeral vegetational cover (Dwivedi and Sreenivas, 2002).

\section{Origin}

The origin of Baropal wetland is connected geologically with the Ghaggar river and Indira Gandhi Canal Project (IGNP). Considering that Ghaggar river originates from the sub-Himalayan region of Himachal Pradesh and flows through Punjab, Haryana and Rajasthan. The present ephemeral nature of the river allows it to terminate into the north-western part of Rajasthan and occasionally it enters into south-eastern Pakistan. During the monsoon period, the river carries a massive amount of water and causes the floods into western parts of Haryana and north-eastern parts of Rajasthan (Kundu, 2012; Chatterjee and Ray, 2018). The ephemeral nature and shallow riverbed of Ghaggar river enable it for a wider floodplain, which can easily be flooded out and become a cause for disaster in north-western Rajasthan (Maemoku et al., 2012). The continuous seasonal flooding in human settlement areas and agricultural fields demanded to escalate a permanent solution for this severe natural problem. In 1960 the state government framed a flood controlling resolution and initiated a project to dispose-off the floodwater into the nearby extensive desert area of Suratgarh, which was an unproductive sand-dune terrain. In this project, 18 natural interdunal depressions were selected to drain the floodwater. For that, few artificial drainage passages were constructed to interlink the interdunal depressions with each other. Another side of the project, a Ghaggar Diversion Canal (GDC) was constructed to transfer the water from the main river tributary to interdunal depressions. This architectural reformation has proved as a working solution of the seasonal flood problem in north-western Rajasthan. From 19701980, incredibly, these interdunal depressions were also started to fill by the excess water of IGNP (Indira Gandhi Canal Project) along with the seasonal supply of Ghaggar river water. Notably, the amount of the allocated water in IGNP was large to consume in the initial years of the project due to the lack of IGNP distribution system. The IGNP (Indira Gandhi Canal Project) was executed to convert 0.15 million hectares of semi-arid and arid wastelands into croplands of north-western Rajasthan (Dwivedi and Sreenivas, 2002). Further, drainage of water into interdunal depressions developed periodic water reservoirs in the region. It became the cause of a new upcoming ecological problem- the origin of the water-logging in nearby lowlands by seepage water. Water-logging in lowlands degraded the economically important agricultural lands of the region. The further investigation disclosed that the gypsiferous layer of the region is playing a tangible role in the formation of water-logging in nearby lowlands. Since subsurfaced hard gypsum layers tend to inhibit the water percolation and promote the water seepage towards lowlands. Over time, few water-logged lowlands have been established as stable wetlands. 
Among these wetlands, Baropal wetland appeared as the largest wetland covering the almost 12 square $\mathrm{km}$ area. Interestingly, Baropal wetland is recharging by the underground seepage channels of Ghaggar river, interdunal depressions and IGNPSuratgarh branch, which is passing through the lateral side of the Baropal wetland.

\section{Ecological Heterogeneity}

Certainly, water-logging has negative socioeconomic impacts ( $\mathrm{Su}$ et al., 2018). Besides, Baropal wetland has been established as a rich biodiversity amphitheatre within the semi-desert region. That is the real example of rapid succession and species aggregation in the barren land. Not surprisingly, upper northern Rajasthan, itself is also an example of the conversion of the desert to extensive agriculture lands, which has been possible by the arrival of Gang Canal, Bhakra Canal Project and IGNP. It has resulted improvement in agricultural production, regional development and modification in the ecology of the region (Singh, 1995). Due to plenty of water supply in Baropal wetland stretch, consequently, ecological succession took place, and vegetation cover of Baropal wetland stretch changed into Xerophytic to Mesophytic and Hydrophytic. It has established enormous plant and animal communities in a short period. In the present picture, the plant communities of Baropal wetland are much productive to support enough food and habitat to a variety of organisms. In comparison to the entire geographical region, Baropal wetland carries a great species diversity and ecological heterogeneity. The availability of water and enough food supply throughout the year emphatically attracted few migratory birds. Furthermore, it has been recorded that Bar-headed Geese and Coots migrate from the Tibetan Plateau to Baropal wetlands (Gogi, 2002). The bird community of Baropal wetland includes the Demoiselle Cranes (Anthropoides virgo), Bareheaded Geese (Anser indicus), Spot bill Duck (Anas poecilorhyncha), Mallard Common Teal (Anas crecca), Common Pochard Duck (Aythya ferina), Pin Tail Duck (Anas acute), Shoveller (Anas clypeata), Tufted Duck (Aythya fuligula), Wigeon (Anas Penelope), Coots, and different kind of Waders (Gogi, 2002). Besides the water birds, many fishes, amphibians, insects, spiders are sharing this small collective habitat. Through a systematic study, 28 species of spider belonging to 9 families reported in the Baropal wetland peripheral area, which is highest in the entire region (Malhotra et al., 2019). Therefore, scientific and taxonomical investigations are required for further floral and faunal studies.

\section{Recognition and eligibility for Protective site}

The observations noted by the local villagers and researchers reveal that the population of the native and migratory birds has risen in the last few years due to some reasons. Increase in food resources within the wetland, distant location, the protection given by the villagers, and quite less interference of unusual visitors are the possible reasons that were identified. One other strong possible reason was predicted that Baropal wetland is the safest place for the migratory birds in the pathway of Afghanistan-Pakistan corridor that is used by the Siberian crane as a second route for migration (Mirande and Harris, 2019) or many other migratory birds. Seeing that annoyance is being intensified by the terrorist activities in the Afghanistan-Pakistan corridor, especially in Lake $A b-i-I s t a d a$. So, it has risen the preference for Baropal wetland and other similar wetlands by the migratory birds. Since the Baropal wetland is acting as a haven for the many native and migratory creatures, the state government should address the importance of the Baropal wetland for biodiversity conservation viewpoint.

\section{Archeological Significance}

The locality of Baropal wetland comes under the floodplain of Ghaggar river. In the same locality, geologists are already working to discover the relationship between Ghaggar and Saraswati rivers through the stable isotopic and geomagnetic study of the Ghaggar riverbed sediments (Sankaran, 1999; Tripathi et al., 2004; Mishra and Mallick, 2008; Maemoku et al., 2012). The Ghaggar floodplain carries the approximately 1500 archaeological sites, and ASI (Archaeological Survey of India) believes that this ancient human settlement is synonymous to the Indus Valley Civilisation. One fully excavated Kalibangan site, near to Baropal wetland (approximately $15 \mathrm{~km}$ faraway) has shown temporal and visual similarity with the Indus Valley Civilisation (Miller, 1985; Kenoyer, 1991). Therefore, Archaeologists are working to identify the shape and status of this ancient human settlement in the Ghaggar floodplain (Chatterjee and Ray, 2018). Another side, 
Ecologists are working to measure the impact of the emergence of the IGNP in this region on various levels ranging from habitat to socio-economic (Sharma and Gaur, 2005; Rao, 2009; Sivaperuman and Baqri, 2009; Roy et al., 2016). Thus, it is an attractive place for every scientific person.

\section{Conclusion}

We reach to a conclusion through meticulous literature citing and referencing that Baropal wetland has not received any ecological attention despite being a water body and always ignored due to the inadequacy in the number of the wellestablished local researchers. Its value has always been superimposed by the archaeological sites, which are present in the same locality (Ghaggar floodplain), and by the Ghaggar and Saraswati rivers debate. Thereby, a systematic and

\section{References}

Chatterjee, A. and Ray, J. S. 2018. Geochemistry of Harappan potteries from Kalibangan and sediments in the Ghaggar River: Clues for a dying river. Geoscience Frontiers, 9(4): 1203-1211.

Dwivedi, R. S. and Sreenivas, K. 2002. The vegetation and waterlogging dynamics as derived from spaceborne multispectral and multitemporal data, International Journal of Remote Sensing, 23(14): 2729-2740.

Garg, D. and Soni, A. K. 2016. Seasonal Variations of PhysicoChemical Characteristics of Badopal Wetland (Water Logged Area), Hanumangarh District, North Rajasthan, India. Remarking an Analisation, 1(8): 9-13.

Gogi, S. 2002. Flamingoes of Baropal Lake. The Tribune, 24 March 2002. p.21.

Keddy, P. 2010. Wetlands: An overview. In Wetland Ecology: Principles and Conservation (pp. 1-41). Cambridge: Cambridge University Press.

Kenoyer, J. M. 1991. The Indus valley tradition of Pakistan and western India. Journal of World Prehistory, 5(4): 331-385.

Kundu, S. 2012. Assessment of surface water quality for drinking and irrigation purposes: a case study of Ghaggar River system surface waters. Bulletin of Environment, Pharmacology \& Life Sciences, 1(2): 1-1.

Maemoku, H., Shitaoka, Y., Nagatomo, T. and Yagi, H. 2012. Geomorphological constraints on the Ghaggar River regime during the Mature Harappan period, in Climates, Landscapes, and Civilizations, Geophys. Monogr. Ser., vol. 198, edited by L. Giosan et al., 97-106, AGU, Washington, D. C. comprehensive work has not been performed to investigate the biological wealth of the Baropal and other nearby wetlands except for spider fauna. In March 2013, Rajasthan State Government proposed to list it for a bird sanctuary but nothing significant has been done yet. As per our observations and frequent visits to Baropal wetland to study the spider fauna, we noticed that it carries a high species diversity and ecological heterogeneity due to the availability of water and enough food supply throughout the year. Since Baropal wetland is an undiscovered and solitary large wetland of the region, it has great possibilities for further ecological implications. As our opinion, Baropal wetland can become an ideal site to conduct several experimental studies of riparian land ecology, in addition to the geological, archaeological and socio-economic account of the Ghaggar floodplain.

Malhotra, G. S., Kapoor, N. and Saxena, M. M. 2019. Spider diversity and abundance in different habitats of UpperNorthern Rajasthan, ESSENCE-International Journal for Environmental Rehabilitation and Conservation, 10(1): $1-14$.

Mamatamayee, C. 1991. Pioneers of the Settlement at Kalibangan. Journal of Human Ecology, 2(2), 159-164.

Miller, D. 1985. Ideology and the Harappan civilization. Journal of Anthropological Archaeology, 4(1): 34-71.

Mirande, C. M. and Harris, J. T. 2019. Crane Conservation Strategy. International Crane Foundation, Baraboo, WI.

Mishra D. C. and Mallick, K. 2008. Paleochannels and settlements of Harappan period in kalibangan, Rajasthan based on geophysical investigations, Current Science, 95(12): 1657-1658.

Moharana, P. C. 2012. Types, distribution and morphology of aeolian bedforms in canal-irrigated region of arid western Rajasthan. Journal of Indian Geomorphology, 1: 1-7.

Ramakrishnan, M. and Vaidyanadhan, R. 2010. Geology of India (Vol. 1 \& 2). GSI Publications, 2(1).

Rao, A. S. 2009. Climate and microclimate changes influencing the fauna of the hot Indian arid zone. In Faunal ecology and conservation of the Great Indian Desert (pp. 13-23). Springer, Berlin, Heidelberg.

Roy, M. M., Yadava, N. D., Soni, M. L. and Tewari, J. C. 2016. Combating Waterlogging in IGNP Areas in Thar Desert (India): Case Studies on Biodrainage. In Agroforestry for the Management of Waterlogged Saline 


\section{Malhotra and Madan}

Soils and Poor-Quality Waters (pp. 109-120). Springer, New Delhi.

Sankaran, A.V. 1999. Saraswati- the ancient river lost in the desert. Current science, 77(8): 1054-1060.

Sharma, R. C. and Gaur, S. 2005. Changing ecology and faunal diversity of amphibians and reptiles in the Thar Desert of Rajasthan, India. Changing Faunal Ecology in the Thar Desert, Kumar Scientific Publishers, Jodhpur, 149-171.

Singh, B.P., 1995. Impact of canal irrigation on the natural flora of Rajasthan. Rheedea, 5: 90-92.

Sinha-Roy, S., Malhotra, G. and Mohanty, M. 1998. Geology of Rajasthan. Geological Society of India.

Sivaperuman C. and Baqri Q. H. 2009. Avifaunal Diversity in the IGNP Canal Area, Rajasthan, India. In: Sivaperuman
C., Baqri Q.H., Ramaswamy G., Naseema M. (eds) Faunal Ecology and Conservation of the Great Indian Desert. Springer, Berlin, Heidelberg.

Su, M., Zheng, Y., Hao, Y., Chen, Q., Chen, S., Chen, Z. and Xie, H. 2018. The influence of landscape pattern on the risk of urban water-logging and flood disaster. Ecological Indicators, 92: 133-140.

Thapar, B. K. 1975. Kalibangan: a Harappan metropolis beyond the Indus Valley. Expedition, 17(2): 19.

Tiner, R. W. 2016. Wetland indicators: A guide to wetland formation, identification, delineation, classification, and mapping. CRC Press.

Tripathi, J. K., Bock, B., Rajamani, V. and Eisenhauer, A. 2004. Is river Ghaggar, Saraswati? Geochemical constraints. Current Science, 87: 1141-1145. 